

\title{
AN ANALYSIS OF THE EFFECT OF PRICING STRATEGIES ON PROFITABILITY OF INSURANCE FIRMS IN KENYA
}

\author{
${ }^{1 *}$ Perminus Kariuki Nyaga, \\ ${ }^{\text {1*}}$ Post Graduate Student,School of Business \\ Methodist University \\ *Corresponding Author's Email: kariopermi@gmail.com \\ ${ }^{2 *}$ Mr. Wilson Muema, \\ ${ }^{1 *}$ Lecturer,School of Business \\ Methodist University
}

\begin{abstract}
Purpose: The objectives of the study were to establish the effect of economy, skimming, penetration and premium pricing strategies on the profitability of insurance firms in Kenya.

Methodology:The descriptive research design was preferred to other research designs because it reports the status of study variables. The population of study was the 45 insurance companies operating in Kenya as at $31^{\text {st }}$ December 2012. Data was drawn from a period of five (5) years that is 2008-2012. The sample of this study was $10 \%$ of the sales workforce which comprised of 900 employees from the 45 insurance companies. The sample was generated by purposively sampling two employees from each insurance company. The researcher collected primary data with the help of a questionnaire. The primary data obtained from the questionnaires was summarized and analyzed by use of descriptive and inferential statistical techniques.
\end{abstract}

Results:Regression and correlation results indicated that there was a statistically significant and positive relationship between economy pricing, skimming pricing, penetration pricing, premium pricing, price optimization strategies, strategies and profitability. Results show that economy pricing, skimming pricing, penetration pricing, premium pricing, price optimization strategies have a positive effect on the profitability of insurance companies. The correlation between profitability and penetration, premium and price optimization strategies was strong and positive. The regression results indicate that the variables; economy pricing, penetration pricing, premium pricing, price optimization strategy and skimming pricing were satisfactorily explaining profitability.

Policy recommendation: The study recommends that insurance companies put in place measures assess the most effective pricing strategy to reduce product costs and thus increase profitability whenever such a strategy is used.

Keywords: economy pricing strategy, skimming pricing strategy penetration pricing strategy premium pricing strategy optimization pricing strategy 
International Journal of Finance And Accounting

ISSN xxxx-Xxxx (Paper) ISSN 2518-4113 (Online)

Vol.2, Issue 6, No.3 pp 44- 65, 2017

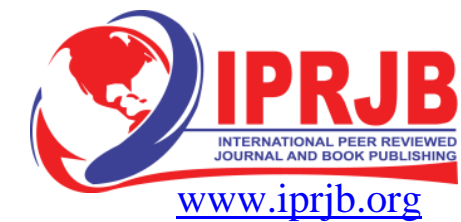

\subsection{Back ground of the Study}

Insurance industry, the world over forms an integral part of the financial services sector and plays a pivotal role in the economic growth of an economy. A well developed insurance market paves way for efficient resource allocation through transfer of risk and mobilization of savings. Insurance industry is well developed in economies such as the US, Europe, Japan, and South Korea. Emerging markets are found throughout Asia, specifically in India and China, and are also in Latin America. In 2012, the global insurance market is forecast to have a value of $\$ 4,608.5$ billion, an increase of $24.9 \%$ since 2007 . Life insurance dominates the global insurance market, accounting for $59.7 \%$ of the market's value (Andersen, 2008).

Insurance pricing, involves the calculation of each policy owner's fair share of losses and expenses. The price paid for insurance, called the premium, is the rate per unit or coverage multiplied by the number of unit purchased. Unit of insurance are measured differently according to the type of coverage. The rates are established before the exposure period to which they apply so that a forecast of the future must be made. The probable number and value of claims are forecast from historical loss experience with consideration given to trends and new developments. Insurers cannot set rates arbitrarily; rates are subject to state control (Andersen, 2008).

\subsection{Statement of the Problem}

Every firm is most concerned with its profitability. One of the most frequently used tools of financial ratio analysis is profitability ratios which are used to determine the company's bottom line. Profitability measures are important to company managers and owners alike. If a small business has outside investors who have put their own money into the company, the primary owner certainly has to show profitability to those equity investors. There has been a growing number of studies recently that test for measures and determinants of firm profitability. Financial industry's profitability has attracted scholarly attention in recent studies due to its importance in performance measurement (Kallhoefer\& Salem, 2008)

According to a study conducted by Ahmed et al (2011) on the determinants of performance, it indicated that size, risk and leverage are important determinants of performance of life insurance companies of Pakistan. According to Wright (1992) due to the unique accounting system used by life insurance companies, profitability of the industry has always been difficult to measure as compared with other financial institutions or corporations. Kasturi (2006) argued that the performance of insurance company in financial terms is normally expressed in net premium earned, profitability from underwriting activities, annual turnover, return on investment and return on equity. However, none of these studies focused on the effects of pricing strategies on the productivity of insurance companies in insurance firms in Kenya. If not properly implemented, pricing strategies adopted by the insurance industry are prone to fail and the more the reason for the study.

\subsection{Research Objectives}

i. To establish the effect of economy pricing strategy on the profitability of insurance firms in Kenya.

ii. To find out the effect of skimming pricing strategy on the profitability of insurance firms in Kenya. 
International Journal of Finance And Accounting

ISSN xxxx-Xxxx (Paper) ISSN 2518-4113 (Online)

Vol.2, Issue 6, No.3 pp 44- 65, 2017

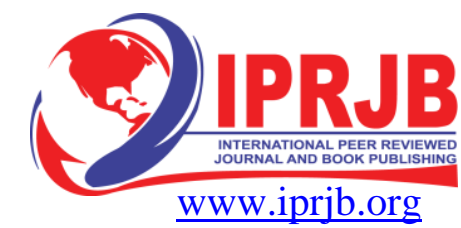

iii. To determine the effect of penetration pricing strategy on the profitability of insurance firms in Kenya.

iv. To establish the effect of premium pricing strategy on the profitability of insurance firms in Kenya.

v. To find out the effect of optimization pricing strategy on the profitability of insurance firms in Kenya.

\subsection{LITERATURE REVIEW}

\subsection{Theoretical Orientation}

\subsubsection{The Weber-Fechner Law}

This law relates changes in a stimulus to the evolved response as follows:

$\mathrm{AS} / \mathrm{S}=\mathrm{k}$, where $\mathrm{S}$ is lie stimulus, AS is the "just noticeable difference" (i.e. so that $\mathrm{S}+\mathrm{AS}$ is perceived to be different from $\mathrm{S}$ ), and $\mathrm{k}$ is constant for each sensory stimulus. Fechner analyzed subjective sensations using differential increments and derived the Weber-Fechner law (Monroe, 1971).

Several authors have applied the Weber-Fechner law in the investigation of price thresholds Adam (1970), Gabor and Granger,(1966) and Monroe, (1973). The empirica1 evidence reported in these papers supports the hypothesis of upper and lower price thresholds and thus a range of prices which is considered acceptable. The Weber-Fechner law provides a means of experimentally determining such thresholds. Prices below the lower threshold are considered too low (quality is suspect) and prices above the upper threshold are considered too high. This was empirically demonstrated by Adam (Monroe, 1973).

The theory is relevant in this study as it is used to explain how perception of prices by consumers affects them in purchasing insurance products. The more the consumers perceive those prices positively the more sales they make hence aiding in making the pricing decisions of the firms specially understanding the threshold of prices of such strategies.

\subsection{Empirical Literature Review}

\subsubsection{Economy Pricing Strategy and Profitability of Insurance Firms}

Ekundayo, (2012) found that in order to meet specific objectives, and within the content of factors that influence pricing decision, firms have to adopt some type of economy pricing strategy. For example, a construction firm that is targeting a particular construction market could do this by tendering for such jobs at a low price level. Fellows and Langford, (2000) suggest that firms may adopt low profit level pricing in times of economic recession in order to maintain market share or to penetrate a new market. Skitmore, (2007) also has investigated economy oriented pricing strategies of construction firms submitting bid prices aimed at what the market will bear.

\subsubsection{Skimming Pricing Strategy}

Besanko and Winston,(2000) found that central assumption of price skimming is because each consumer pays a price at or below his or her reservation price, each consumer is satisfied with his or her purchase. However, beyond the purchase decision, there is scant research on 
International Journal of Finance And Accounting

ISSN xxxx-Xxxx (Paper) ISSN 2518-4113 (Online)

Vol.2, Issue 6, No.3 pp 44- 65, 2017

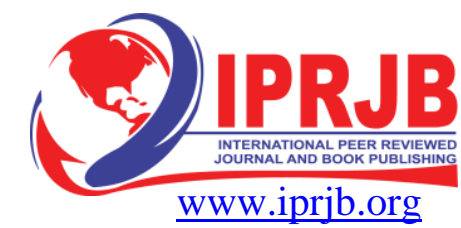

consumers' responses to price skimming. Instead, investigations concern firm profit maximization and variables impacting profit maximization, such as diffusion rates, competition and production learning curves (Robinson and Lakhani 2005; Irwin and Klenow, 2004). Thus, although price skimming is widely used by managers and investigated in the economics and strategy literatures, it has received little attention in consumer research.

\subsubsection{Penetration Pricing Strategy and Profitability of Insurance Firms}

Henard, (2001) odserved that the penetration price strategy is realized by setting a relatively low price for the new product aiming at reaching deeper market penetration in the current period and providing, as well as, a greater market share in subsequent periods. This strategy is applied only in the case when the price of demanded product is at the level which provides a sales volume increase. Therefore, in an industry where the considerable part of total costs could be reduced thanks to the economies of scale and experience, the justified penetration pricing application enables the company to realize greater a profit in the market.

\subsubsection{Premium Pricing Strategy and the Profitability of Insurance Firms}

The earliest efforts to identify the relationship between pricing of risk and the profitability of insurance companies can be attributed to Bain (2001) who developed the concentration profit hypothesis.

\subsubsection{Price Optimization Strategy and the Profitability of Insurance Firms}

Stigler, (2004) observed that prices are decisive for what insurance users buy and how much they pay. Prices are also decisive for efficient provision of services at low cost and for the development of effective competition.

\section{4: Conceptual Framework}

Independent variables

\section{Dependent Variable}

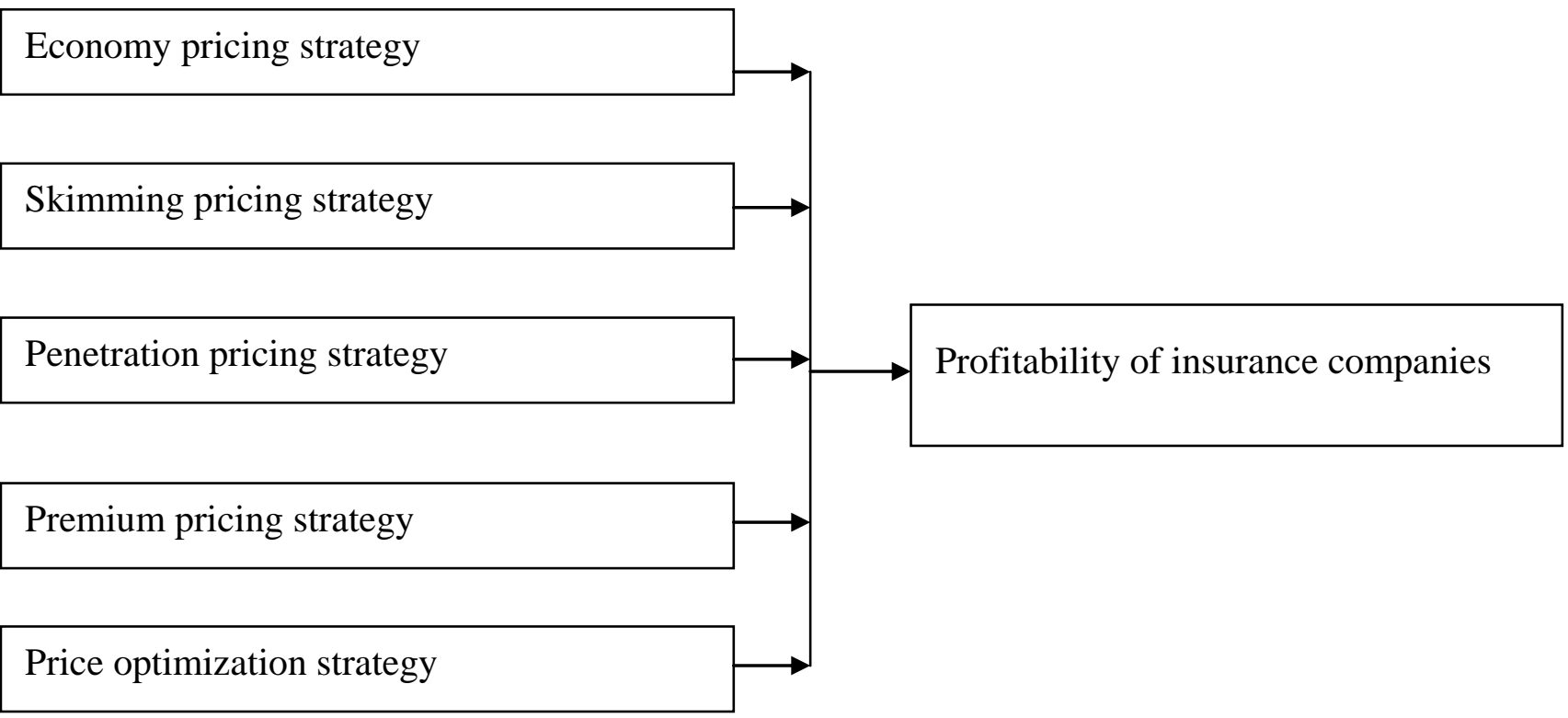


International Journal of Finance And Accounting

ISSN xxxx-Xxxx (Paper) ISSN 2518-4113 (Online)

Vol.2, Issue 6, No.3 pp 44- 65, 2017

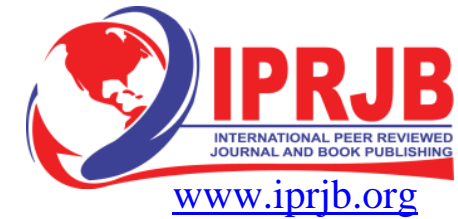

Source: Figure 1: Conceptual Model Researcher (2013)

\subsection{Operational Framework}

\section{Economy pricing}

Increase in sales

Reduction in product costs

Competitive edge

\section{Skimming pricing}

Quick cost recovery

well established products

Low priced products

\section{Penetration pricing}

Wide market acceptance

Discouraging competition

Success in penetration

\section{Premium pricing}

Fair premium pricing

Reduction of operation costs

Professional expertise

Price optimization
strategy
Price changes
Interest and use
Growth in both customer

\section{Figure .2: Operational Framework}

\subsection{METHODOLOGY}

The descriptive research design was preferred to other research designs because it reports the status of study variables. The population of study was the 45 insurance companies operating in Kenya as at $31^{\text {st }}$ December 2012. Data was drawn from a period of five (5) years that is 20082012. The sample of this study was $10 \%$ of the sales workforce which comprised of 900 employees from the 45 insurance companies. The sample was generated by purposively 
International Journal of Finance And Accounting

ISSN xxxx-Xxxx (Paper) ISSN 2518-4113 (Online)

Vol.2, Issue 6, No.3 pp 44- 65, 2017

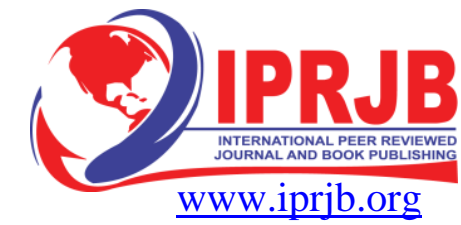

sampling two employees from each insurance company. The researcher collected primary data with the help of a questionnaire. The primary data obtained from the questionnaires was summarized and analyzed by use of descriptive and inferential statistical techniques.

\subsection{RESULTS FINDINGS}

\subsection{Quantitative Data Analysis}

\subsubsection{Economy Pricing Strategy and Profitability of Insurance Companies in Kenya}

The study sought to establish the effect of economy pricing strategy on the profitability of insurance companies. The results were presented in Table 4.7.Seventy five percent of the respondents agreed that there had been an increase in use of the economy pricing strategy in their firm in the recent years. Above eighty two percent $(82.8 \%)$ agreed that there had been an increase in sales of their products as a result of economy pricing strategy. Ninety two point two percent of the respondents agreed on the statement that their company has been in a position to reduce product costs whenever economy pricing of its products was used. Eighty six percent agreed that most of their competitor firms have failed to effectively adopt economy pricing strategies giving them a competitive edge over them. Above seventy nine percent $(79.7 \%)$ agreed that the measures put in place to implement our economy pricing strategies were better compared to competitor firms. The overall likert mean was 3.88 with a standard deviation of 0.86 and this implies that economy pricing greatly influences the profitability of insurance companies.

These findings agree with those of Irwin and Klenow, (2004) who found that the potential detrimental effects to both firms when the firm's economy product pricing rating improves are a direct result of both firms' complete flexibility in adjusting their prices in response to changes to product ratings. They also agree with those of Flanagan and Norman (2006) who examined the economy pricing strategies adopted manufacturing firms and concluded that they resulted in significant effect on profitability.

Table 1 Economy Pricing Strategy and Profitability of Insurance Companies

\begin{tabular}{|c|c|c|c|c|c|c|c|}
\hline Statement & $\begin{array}{l}\text { Strongl } \\
\mathbf{y} \\
\text { Disagre } \\
\mathbf{e} \\
\end{array}$ & $\begin{array}{c}\text { Disagre } \\
\mathrm{e}\end{array}$ & Neutral & Agree & $\begin{array}{l}\text { Strongl } \\
\text { y Agree }\end{array}$ & Mean & $\begin{array}{l}\text { Std. } \\
\text { Devia } \\
\text { tion }\end{array}$ \\
\hline $\begin{array}{l}\text { There has been an increase in } \\
\text { use of the economy pricing } \\
\text { strategy in our firm in the recent } \\
\text { years }\end{array}$ & $1.60 \%$ & $14.10 \%$ & $9.40 \%$ & $62.50 \%$ & $12.50 \%$ & 3.7 & 0.92 \\
\hline $\begin{array}{l}\text { There has been an increase in } \\
\text { sales of our products as a result } \\
\text { of economy pricing strategy }\end{array}$ & $3.10 \%$ & $3.10 \%$ & $10.90 \%$ & $67.20 \%$ & $15.60 \%$ & 3.89 & 0.82 \\
\hline $\begin{array}{l}\text { Our company has been in a } \\
\text { position to reduce product costs } \\
\text { whenever economy pricing of its }\end{array}$ & $4.70 \%$ & $3.10 \%$ & $0.00 \%$ & $75.00 \%$ & $17.20 \%$ & 3.97 & 0.85 \\
\hline
\end{tabular}


International Journal of Finance And Accounting

ISSN xxxx-Xxxx (Paper) ISSN 2518-4113 (Online)

Vol.2, Issue 6, No.3 pp 44- 65, 2017

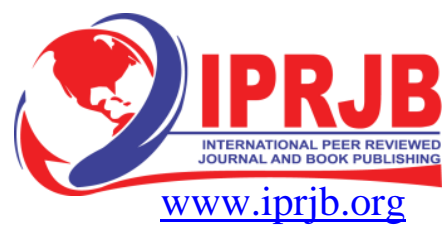

Most of the competitor firms have failed to effectively adopt economy pricing strategies giving us a competitive edge over them

The measures put in place to implement our economy pricing strategies are better compared to $\begin{array}{lllllll}4.70 \% & 4.70 \% & 4.70 \% & 67.20 \% & 18.80 \% & 3.91 & 0.92\end{array}$ competitor firms

Average

$\begin{array}{lllllll}0.00 \% & 7.80 \% & 12.50 \% & 60.90 \% & 18.80 \% & 3.91 & 0.79\end{array}$

\subsubsection{Skimming Price Strategy and Profitability of Insurance Companies in Kenya}

The study sought to establish the effect of skimming pricing strategy on the profitability of insurance companies. The results were presented in Table 4.8.Above seventy nine percent $(79.7 \%)$ of the respondents agreed that the skimming pricing strategy adopted by their firm enabled them to recover cost quickly.Eighty percent of the respondents agreed that their firmcontinued to use skimming pricing even when the products were well established in the market. Majority of the respondents (84.4\%) agreed that their firm had substantial lead in competition with both new and established products making their strategy more effective. Seventy six point six percent agreed that low priced products offered by other firms do not pose a threat to them. Above eighty seven percent (87.5\%) agreed that the skimming pricing strategy adopted by their firm was highly determined by the brand loyalty in their customer base. The overall likert mean was 4.00 with a standard deviation of 0.99 and this implies that skimming pricing greatly influences theprofitability of insurance companies.

The findings agree with those of Richtel\& Andrew, (2004) who investigated the relationship between price skimming and profitability in logistics companies. Prior research has also found skimming pricing information, even when revealed after purchase and consumption, affects profitability levels (Voss, Parasuraman, \&Grewal, 1998; Varki\& Colgate, 2001; Fornell et al. 1999).

Table 2 Skimming Pricing Strategy and Profitability of Insurance Companies

\begin{tabular}{|c|c|c|c|c|c|c|c|}
\hline Statement & $\begin{array}{l}\text { Strongly } \\
\text { Disagree }\end{array}$ & $\begin{array}{l}\text { Disagre } \\
\text { e }\end{array}$ & Neutral & Agree & $\begin{array}{l}\text { Strongl } \\
\text { y Agree }\end{array}$ & Mean & $\begin{array}{l}\text { Std. } \\
\text { Devia } \\
\text { tion }\end{array}$ \\
\hline $\begin{array}{l}\text { The skimming pricing strategy } \\
\text { adopted by our firm enables us } \\
\text { to recover cost quickly }\end{array}$ & $4.70 \%$ & $4.70 \%$ & $10.90 \%$ & $65.60 \%$ & $14.10 \%$ & 3.80 & 0.91 \\
\hline $\begin{array}{l}\text { Our firm continues to use } \\
\text { skimming pricing even the } \\
\text { products are well established in } \\
\text { the market }\end{array}$ & $6.20 \%$ & $7.80 \%$ & $6.0 \%$ & $51.60 \%$ & $28.40 \%$ & 3.87 & 1.10 \\
\hline
\end{tabular}


International Journal of Finance And Accounting

ISSN xxxx-xxxx (Paper) ISSN 2518-4113 (Online)

Vol.2, Issue 6, No.3 pp 44- 65, 2017

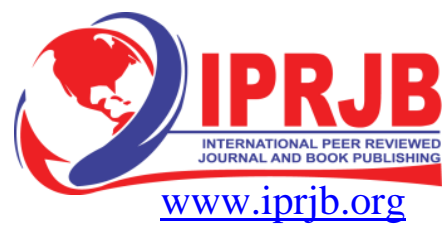

Our firm has substantial lead in competition with both new and established products making
$1.60 \%$
$10.90 \%$
$3.10 \%$
$67.20 \%$
$17.20 \%$
3.88
0.88

our strategy more effective

Low priced products offered by other firms do not pose a threat to us

\begin{tabular}{lllllll}
$3.10 \%$ & $9.40 \%$ & $10.90 \%$ & $42.20 \%$ & $34.40 \%$ & 3.95 & 1.06 \\
& & & & & & \\
$3.10 \%$ & $3.10 \%$ & $6.20 \%$ & $14.10 \%$ & $73.40 \%$ & 4.52 & 0.97 \\
& & & & & & \\
& & & & & $\mathbf{4 . 0 0}$ & $\mathbf{0 . 9 9}$ \\
\hline
\end{tabular}

The skimming pricing strategy adopted by our firm is highly determined by the brand loyalty in our customer base

4.1.3 Penetration Pricing Strategy and Profitability of Insurance Companies in Kenya

The study sought to establish the effect of penetration pricing strategy on the profitability of insurance companies. The results were presented in Table 4.9.Above eighty two percent (82.9\%) agreed that penetration pricing in their firm enabled them secure a wide market acceptance hence a bigger customer base. Majority of the respondents $(85.4 \%)$ agreed that the strategy helps them discourage competition in that it focuses more on acceptance rather than profits. Eighty nine percent of the respondents agreed that their firm adopted penetration pricing when it expected competition with similar products in other firms. Seventy six point five percent agreed that there had been success in the penetration pricing strategy whenever their firm adopted it in the recent past. Above eighty seven percent $(87.5 \%)$ agreed that most of the competitor firms had not been in a position to effectively use penetration pricing as their firm had done. The overall likert mean was 4.00 with a standard deviation of 0.99 and this implies that penetration pricing greatly influences the profitability of insurance companies.

These findings agree with Parkim, (2003) who found that the penetration price strategy is analogous to the maximizing sales strategy with limited profit. They also agree with Szymanski and Henard, (2001) who examined the penetration pricing strategies adopted by the health market place and concluded that the combination of state regulation pervasive pricing and other market peculiarities resulted in significant effect on profitability.

Table 4 Penetration Pricing Strategy and Profitability of Insurance Companies

\begin{tabular}{|c|c|c|c|c|c|c|c|}
\hline Statement & $\begin{array}{l}\text { Strongly } \\
\text { Disagree }\end{array}$ & $\begin{array}{l}\text { Disagre } \\
\text { e }\end{array}$ & Neutral & Agree & $\begin{array}{l}\text { Strongl } \\
\text { y Agree }\end{array}$ & $\begin{array}{l}\text { Mea } \\
\text { n }\end{array}$ & $\begin{array}{l}\text { Std. } \\
\text { Devia } \\
\text { tion }\end{array}$ \\
\hline $\begin{array}{l}\text { Penetration pricing in our firm } \\
\text { enables us secure a wide } \\
\text { market acceptance hence a } \\
\text { bigger customer base }\end{array}$ & $4.70 \%$ & $6.20 \%$ & $6.20 \%$ & $43.80 \%$ & $39.10 \%$ & 4.06 & 1.07 \\
\hline $\begin{array}{l}\text { The strategy helps us } \\
\text { discourage competition in that } \\
\text { it focuses more on acceptance } \\
\text { rather than profits }\end{array}$ & $4.70 \%$ & $4.70 \%$ & $4.70 \%$ & $50.00 \%$ & $35.90 \%$ & 4.08 & 1.01 \\
\hline
\end{tabular}


International Journal of Finance And Accounting

ISSN xxxx-Xxxx (Paper) ISSN 2518-4113 (Online)

Vol.2, Issue 6, No.3 pp 44- 65, 2017

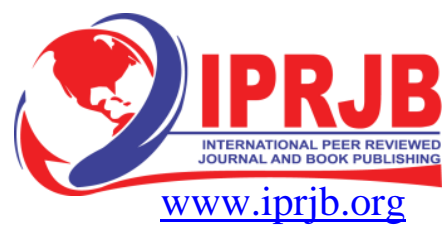

Our firm adopts penetration pricing when it expects competition with similar
$1.60 \% \quad 6.20 \%$
$3.10 \%$
$40.60 \%$
$48.40 \%$
4.28
0.92

products in other firms

There has been success in the penetration pricing strategy whenever our firm adopts it in $7.80 \%$

$3.10 \%$

$12.50 \%$

$65.60 \%$

$10.90 \%$

3.69

0.99

the recent past

Most of the competitor firms

have not been in a position to

effectively use penetration

$3.10 \%$

$4.70 \%$

$4.70 \%$

$46.90 \%$

$40.60 \%$

4.17

0.95

pricing as we have

Average

4.06

0.99

\subsubsection{Premium Pricing Strategy and Profitability of Insurance Companies in Kenya}

The study sought to establish the effect of premium pricing strategy on the profitability of insurance companies. The results were presented in Table 4.10.Seventy five percent of the respondents agreed that their firm positively influenced consumer's perception through fair pricing in setting premium prices. Above seventy eight percent $(78.1 \%)$ agree that when using premium pricing their firm tried to reduce operation costs as much as possible and ensure they are controlled. Majority of the respondents (73.4\%) agreed that their firm has successfully adopted effective premium pricing strategies in the recent years. Our premium pricing strategy has led to more sales in their insurance products. Above sixty percent $(60.9 \%)$ agreed that their firm engages professional expertise inimplementation of their premium pricing strategy. The overall likert mean was 3.71 with a standard deviation of 1.190 and this implies that premium pricing greatly influences the profitability of insurance companies.

The findings are consistent with Baytelsmit and Bouzouita, (1998) who using premium pricing examined the market, market structure and industry profitability relationship within the non life insurance market and found a significant relationship, concluding that the pricing structure and characteristics of the market place contribute to a reduced level of competition among insurers

Table 5 Premium Pricing Strategy and Profitability of Insurance Companies

\begin{tabular}{|c|c|c|c|c|c|c|c|}
\hline Statement & $\begin{array}{l}\text { Strongl } \\
\text { y } \\
\text { Disagre } \\
\text { e }\end{array}$ & Disagree & Neutral & Agree & $\begin{array}{l}\text { Strongly } \\
\text { Agree }\end{array}$ & Mean & $\begin{array}{l}\text { Std. } \\
\text { Devia } \\
\text { tion }\end{array}$ \\
\hline $\begin{array}{l}\text { Our firm positively } \\
\text { influences consumer's } \\
\text { perception through fair } \\
\text { pricing in setting premium } \\
\text { prices }\end{array}$ & $4.70 \%$ & $10.90 \%$ & $9.40 \%$ & $48.40 \%$ & $26.60 \%$ & 3.81 & 1.10 \\
\hline
\end{tabular}


International Journal of Finance And Accounting

ISSN xxxx-Xxxx (Paper) ISSN 2518-4113 (Online)

Vol.2, Issue 6, No.3 pp 44- 65, 2017

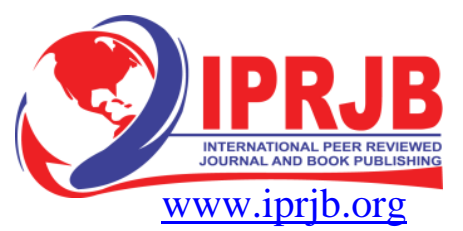

When using premium pricing our firm tries to reduce operation costs as much as possible and ensure they are controlled Our firm has successfully adopted effective premium pricing strategies in the recent years

Our premium pricing strategy has led to more sales in our insurance products

Our firm engages professional expertise in implementation of our $\begin{array}{lllllll}6.20 \% & 10.90 \% & 4.70 \% & 42.20 \% & 35.90 \% & 3.91 & 1.19\end{array}$ premium pricing strategy

$\begin{array}{lllllll}4.70 \% & 10.90 \% & 10.90 \% & 40.60 \% & 32.80 \% & 3.86 & 1.12\end{array}$

$\begin{array}{lllllll}7.80 \% & 17.20 \% & 14.10 \% & 29.70 \% & 31.20 \% & 3.59 & 1.31\end{array}$

$\begin{array}{lllllll}12.50 \% & 10.90 \% & 15.60 \% & 48.40 \% & 12.50 \% & 3.38 & 1.22\end{array}$

Average

$3.71 \quad 1.19$

\subsubsection{Price Optimization Strategy and Profitability of Insurance Companies in Kenya}

The study sought to establish the effect of price optimization strategy on the profitability of insurance companies. The results were presented in Table 4.11. Fifty nine point three percent of the respondents agreed that the interest and use of price optimization strategy by insurance companies had been growing in the last decade. Above sixty five percent $(65.6 \%)$ agree that the strategy adopted by their firm in optimizing price had led to increase in sales.Sixty seven point two percent agreed that there had been growth in both customer base and profits as a result of the optimal pricing strategy adopted by their firm. About sixty eight percent (68.8\%) agreed that they used price increases and decreases to achieve price optimization of the everyday business. About sixty eight percent $(68.7 \%)$ agreed that prices of similar products offered by other firms were not a threat to their firm. The overall likert mean was 3.68 with a standard deviation of 1.1318 and this implies that price optimization strategy greatly influences the profitability of insurance companies.

The findings agree with those in a study by Joskow, (2003) who examined the competitive market structure of the non-life insurance market place and concluded that the combination of state regulation price optimization strategy and other market peculiarities resulted in significant effect on profitability. 
International Journal of Finance And Accounting

ISSN xxxx-Xxxx (Paper) ISSN 2518-4113 (Online)

Vol.2, Issue 6, No.3 pp 44- 65, 2017

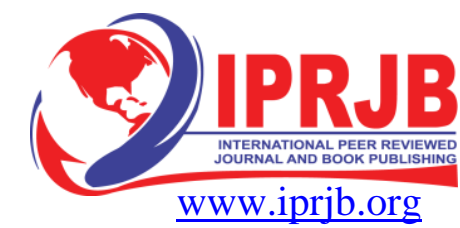

Table 5 Price Optimization Strategy and Profitability of Insurance Companies

\begin{tabular}{|c|c|c|c|c|c|c|c|}
\hline Statement & $\begin{array}{l}\text { Strongly } \\
\text { Disagree }\end{array}$ & $\begin{array}{l}\text { Disagre } \\
\text { e }\end{array}$ & Neutral & Agree & $\begin{array}{l}\text { Strongl } \\
\text { y Agree }\end{array}$ & Mean & $\begin{array}{l}\text { Std. } \\
\text { Devia } \\
\text { tion }\end{array}$ \\
\hline $\begin{array}{l}\text { The interest and use of price } \\
\text { optimization strategy by } \\
\text { insurance companies has been } \\
\text { growing in the last decade }\end{array}$ & $17.20 \%$ & $10.90 \%$ & $12.50 \%$ & $31.20 \%$ & $28.10 \%$ & 3.42 & 1.45 \\
\hline $\begin{array}{l}\text { The strategy adopted by our } \\
\text { firm in optimizing price has led } \\
\text { to increase in sales }\end{array}$ & $9.40 \%$ & $14.10 \%$ & $10.90 \%$ & $29.70 \%$ & $35.90 \%$ & 3.69 & 1.34 \\
\hline $\begin{array}{l}\text { There has been an growth in } \\
\text { both customer base and profits } \\
\text { as a result of the optimal } \\
\text { pricing strategy adopted by our } \\
\text { firm }\end{array}$ & $9.40 \%$ & $9.40 \%$ & $14.10 \%$ & $46.90 \%$ & $20.30 \%$ & 3.59 & 1.19 \\
\hline $\begin{array}{l}\text { We use price increases and } \\
\text { decreases to achieve price } \\
\text { optimization of the everyday } \\
\text { business }\end{array}$ & $6.20 \%$ & $10.90 \%$ & $14.10 \%$ & $29.70 \%$ & $39.10 \%$ & 3.84 & 1.24 \\
\hline $\begin{array}{l}\text { Prices of similar products } \\
\text { offered by other firms are not a } \\
\text { threat to us }\end{array}$ & $10.90 \%$ & $7.80 \%$ & $12.50 \%$ & $23.40 \%$ & $45.30 \%$ & 3.84 & 1.37 \\
\hline Average & & & & & & 3.68 & 1.32 \\
\hline
\end{tabular}

\subsection{Cross Tabulation Tables and Mean Scores}

The mean scores of the independent variables were presented here. The variables were also ranked using the mean score as the criteria. Penetration pricing was the highest ranked in terms of effectiveness followed by skimming, economy, premium pricing and price optimization strategy in that order. The findings implied that penetration pricing is the most adopted practice in pricing strategies by insurance companies.

\section{Table 6Cross Tabulation Tables and Mean Scores}

\begin{tabular}{lcc}
\hline Variable & Mean Score & Ranking \\
\hline Penetration Pricing & 4.06 & 1 \\
Skimming Pricing & 4.01 & 2 \\
Economy & 3.88 & 3 \\
Premium Pricing & 3.71 & 4 \\
Price optimization strategy & 3.68 & 5 \\
\hline
\end{tabular}

\subsection{Pearson's Correlation Analysis}

Bivariate correlation indicates the relationship between two variables. It ranges from 1 to -1 where 1 indicates a strong positive correlation and a -1 indicates a strong negative correlation 
International Journal of Finance And Accounting

ISSN xxxx-Xxxx (Paper) ISSN 2518-4113 (Online)

Vol.2, Issue 6, No.3 pp 44- 65, 2017

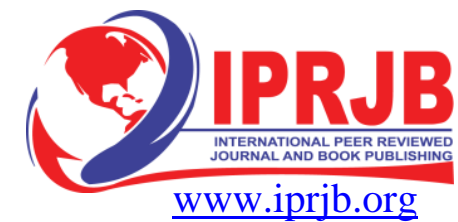

and a zero indicates lack of relationship between the two variables. The closer the correlation tends to zero the weaker it becomes. The correlation between profitability and economy pricing strategy was strong and positive (0.706) and was statistically significant (0.000). The correlation between profitability and skimming was also strong and positive (0.693) and was statistically significant (0.000). The correlation between profitability and penetration, premium and price optimization strategies was strong and positive $(0.688,0.522$, and 0.644 respectively). All the three variables were statistically significant as they each had a significance level of 0.000 .

Table 7 Pearson's Correlation Analysis

\begin{tabular}{|c|c|c|c|c|c|c|c|}
\hline & & ROA & Economy & $\begin{array}{l}\text { Skimmi } \\
\text { ng }\end{array}$ & $\begin{array}{l}\text { Penetra } \\
\text { tion }\end{array}$ & $\begin{array}{l}\text { Premi } \\
\text { um }\end{array}$ & $\begin{array}{l}\text { Optimi } \\
\text { zation }\end{array}$ \\
\hline \multirow{3}{*}{$\mathrm{ROA}$} & Pearson & & & & & & \\
\hline & Correlation & 1.000 & & & & & \\
\hline & Sig. (2-tailed) & & & & & & \\
\hline \multirow{3}{*}{ Economy } & Pearson & & & & & & \\
\hline & Correlation & 0.706 & 1.000 & & & & \\
\hline & Sig. (2-tailed) & 0.000 & & & & & \\
\hline \multirow{3}{*}{ Skimming } & Pearson & & & & & & \\
\hline & Correlation & 0.693 & 0.651 & 1.000 & & & \\
\hline & Sig. (2-tailed) & 0.000 & 0.000 & & & & \\
\hline \multirow{4}{*}{ Penetration } & Pearson & & & & & & \\
\hline & Correlation & 0.688 & 0.644 & 0.789 & 1.000 & & \\
\hline & Sig. (2-tailed) & 0.000 & 0.000 & 0.000 & & & \\
\hline & Pearson & & & & & & \\
\hline \multirow[t]{2}{*}{ Premium } & Correlation & 0.522 & 0.632 & 0.797 & 0.716 & 1.000 & \\
\hline & Sig. (2-tailed) & 0.000 & 0.000 & 0.000 & 0.000 & & \\
\hline & Pearson & & & & & & \\
\hline \multirow[t]{2}{*}{ Optimization } & Correlation & 0.644 & 0.580 & 0.729 & 0.744 & 0.755 & 1.000 \\
\hline & Sig. (2-tailed) & 0.000 & 0.000 & 0.000 & 0.000 & 0.000 & \\
\hline
\end{tabular}

\subsection{Regression Analysis}

Table 7 below shows the fitness of the regression model in explaining the variables under study. The results indicate that the variables; economy pricing, penetration pricing, premium pricing, price optimization strategy and skimming pricing were satisfactorily explaining profitability. This conclusion is supported by the $\mathrm{R}$ square of 0.651 . This further means that the independent variables can explain $65.1 \%$ of the independent variable (profitability).

Table 8 Model Fitness

\begin{tabular}{lc}
\hline Indicator & Coefficient \\
\hline $\mathrm{R}$ & 0.807 \\
R Square & 0.651 \\
Adjusted R Square & 0.620 \\
Std. Error of the Estimate & 0.0778 \\
\hline
\end{tabular}


International Journal of Finance And Accounting

ISSN xxxx-Xxxx (Paper) ISSN 2518-4113 (Online)

Vol.2, Issue 6, No.3 pp 44- 65, 2017

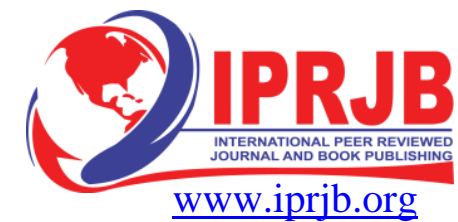

\subsection{Analysis of Variance}

ANOVA statistics presented on Table 4.15 indicate that the overall model was statistically significant. This was supported by a probability (p) value of 0.000 . The reported $p$ value was less than the conventional probability of 0.05 significance levels thus its significance in the study. These results indicate that the independent variables are good predictors of performance in terms of profitability.

The findings led to rejection of null hypothesis that economy pricing, skimming pricing, penetration pricing, premium pricing and price optimization strategies did not significantly contributeto financial performance of insurance companies.

Table 9Analysis of Variance

\begin{tabular}{llccccc}
\hline Model & & Sum of Squares & df & Mean Square & F & Sig. \\
\hline & Regression & 0.653 & 5 & 0.131 & 21.596 & 0.000 \\
& Residual & 0.351 & 58 & 0.006 & & \\
& Total & 1.004 & 63 & & & \\
\hline
\end{tabular}

Regression of coefficients results in Table 4.16 shows that there is a positive relationship between profitability and economy pricing, skimming pricing, penetration pricing, premium pricing and price optimization strategy and whose beta coefficients are $0.069,0.051,0.052$, 0.042 and 0.021 respectively. All the variables under study were statistically significant as they were all below the probability conventional of 0.05 . These results indicate that profitability is determined by economy pricing, skimming pricing, penetration pricing, premium pricing and price optimization strategies.

The results indicate that; an increase in the economy pricing strategies by one unit leads to an increase in profitability by 0.069 units; an increase in the skimming pricing strategies by one unit leads to an increase in profitability by 0.051 units; an increase in the penetration pricing by one unit leads to an increase in profitability by 0.052 units; an increase in the premium pricing strategies by one unit leads to an increase in profitability by 0.042 units; an increase in the price optimization strategies by one unit leads to an increase in profitability by 0.021 units.

Table 10 Regression of Coefficients

\begin{tabular}{lcccc}
\hline & B & Std. Error & t & Sig. \\
\hline (Constant) & -0.551 & 0.075 & -7.390 & 0.000 \\
Economy & 0.069 & 0.017 & 4.018 & 0.000 \\
Skimming & 0.051 & 0.0028 & 18.21429 & 0.000 \\
Penetration & 0.052 & 0.028 & 1.847 & 0.030 \\
Premium & 0.042 & 0.0018 & 23.33333 & 0.021 \\
Optimization & 0.021 & 0.0016 & 13.125 & 0.007 \\
\hline
\end{tabular}

\subsection{Summary Equations}

The summary equation was; 
International Journal of Finance And Accounting

ISSN xxxx-Xxxx (Paper) ISSN 2518-4113 (Online)

Vol.2, Issue 6, No.3 pp 44- 65, 2017

ROA $=-0.551+0.069$ Economy pricing +0.051 Skimming pricing +0.052 Penetration

Pricing + 0.042Premium Pricing +0.021 Price optimization strategy

\subsection{SUMMARY OF FINDINGS, CONCLUSIONS AND RECOMMENDATIONS}

\subsection{Summary of study}

This section attempted to summarize the findings that were obtained in chapter four.

\subsubsection{Economy Pricing Strategy and Profitability of Insurance Companies}

The first objective was to establish the effect of economy pricing strategies on the profitability of insurance firms in Kenya. The descriptive statistics indicated that majority of the respondents agreed that there had been an increase in use of the economy pricing strategy in their firm in the recent years, there had been an increase in sales of their products as a result of economy pricing strategy, their company has been in a position to reduce product costs whenever economy pricing of its products was used, most of the competitor firms had failed to effectively adopt economy pricing strategies giving them a competitive edge over them and the measures put in place to implement them economy pricing strategies are better compared to competitor firms. Regression and correlation results indicated that there was a statistically significant and positive relationship between economy pricing strategies and profitability. These results implied that economy pricing has a positive effect on the profitability of insurance companies. The findings agree with those of Flanagan and Norman (2006) who examined the economy pricing strategies adopted manufacturing firms and concluded that they resulted in significant effect on profitability.

\subsubsection{Skimming Pricing Strategy and Profitability of Insurance Companies}

The second objective was to establish the effect of skimming pricing strategies on the profitability of insurance firms in Kenya. The descriptive statistics indicated that majority of the respondents agreed that the skimming pricing strategy adopted by their firm enabled us to recover cost quickly, their firm continued to use skimming pricing even when the products were well established in the market, their firm has substantial lead in competition with both new and established products making their strategy more effective, low priced products offered by other firms did not pose a threat to them and the skimming pricing strategy adopted by our firm was highly determined by the brand loyalty in their customer base. Regression and correlation results indicated that there was a statistically significant and positive relationship between skimming pricing strategies and profitability.

These results implied that skimming pricing has a positive effect on the profitability of insurance companies. The findings agree with those of Richtel\& Andrew, (2004) who investigated the relationship between price skimming and profitability in logistics companies. Prior research has also found skimming pricing information, even when revealed after purchase and consumption, affects profitability levels (Voss, Parasuraman, \&Grewal, 1998; Varki\& Colgate, 2001; Fornell et al. 1999).

\subsubsection{Penetration Pricing Strategy and Profitability of Insurance Companies}

The third objective was to establish the effect of penetration pricing strategies on the profitability of insurance firms in Kenya. The descriptive statistics indicated that majority of the respondents 
International Journal of Finance And Accounting

ISSN xxxx-Xxxx (Paper) ISSN 2518-4113 (Online)

Vol.2, Issue 6, No.3 pp 44- 65, 2017

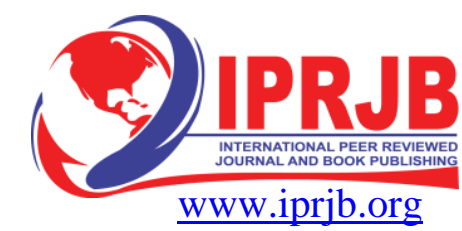

agreed that penetration pricing in their firm enabled them secure a wide market acceptance hence a bigger customer base, the strategy helped them discourage competition in that it focused more on acceptance rather than profits, their firm adopted penetration pricing when it expected competition with similar products in other firms, there had been success in the penetration pricing strategy whenever the firm adopted it in the recent past and most of the competitor firms had not been in a position to effectively use penetration pricing as the firm had. Regression and correlation results indicated that there was a statistically significant and positive relationship between penetration pricing strategies and profitability. These results implied that penetration pricing has a positive effect on the profitability of insurance companies.

These findings agree with Parkim, (2003) who found that the penetration price strategy is analogous to the maximizing sales strategy with limited profit. They also agree with Szymanski and Henard, (2001) who examined the penetration pricing strategies adopted by the health market place and concluded that the combination of state regulation pervasive pricing and other market peculiarities resulted in significant effect on profitability.

\subsubsection{Premium Pricing Strategy and Profitability of Insurance Companies}

The forth objective was to establish the effect of premium pricing strategies on the profitability of insurance firms in Kenya. The descriptive statistics indicated that majority of the respondents agreed that their firm positively influenced consumer's perception through fair pricing in setting premium prices, when using premium pricing our firm tried to reduce operation costs as much as possible and ensured they are controlled, their firm had successfully adopted effective premium pricing strategies in the recent years, their premium pricing strategy had led to more sales in their insurance products and their firm engaged professional expertise in implementation of their premium pricing strategy. Regression and correlation results indicated that there was a statistically significant and positive relationship between premium pricing strategies and profitability. These results implied that premium pricing has a positive effect on the profitability of insurance companies.

\subsubsection{Price Optimization Strategy and Profitability of Insurance Companies}

The fifth objective was to establish the effect of price optimization strategies on the profitability of insurance firms in Kenya. The descriptive statistics indicated that majority of the respondents agreed that the interest and use of price optimization strategy by insurance companies had been growing in the last decade, the strategy adopted by their firm in optimizing price had led to increase in sales, there had been growth in both customer base and profits as a result of the optimal pricing strategy adopted by their firm, they used price increases and decreases to achieve price optimization of the everyday business and prices of similar products offered by other firms were not a threat to them. Regression and correlation results indicated that there was a statistically significant and positive relationship between price optimization strategies and profitability. These results implied that price optimization strategy has a positive effect on the profitability of insurance companies.

\subsection{Conclusion}

Based on the objectives and the findings of the study the following conclusion can be made; 
International Journal of Finance And Accounting

ISSN xxxx-Xxxx (Paper) ISSN 2518-4113 (Online)

Vol.2, Issue 6, No.3 pp 44- 65, 2017

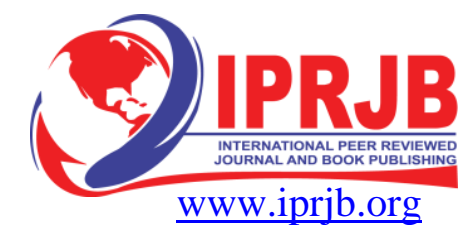

The first objective was to establish the effect of economy pricing strategies on the profitability of insurance firms in Kenya. From the study it can be concluded that the insurance companies had put in place effective economy pricing measures as firms had ensured reduction of product costs giving them a competitive edge over their rivals. It can also be concluded that economy pricing was a strong determinant of insurance company's profitability.

The second objective was to establish the effect of skimming pricing strategies on the profitability of insurance firms in Kenya. It was also possible to conclude that the insurance companies had put in place effective skimming pricing practices as they helped them to recover cost quickly enabling firms to have substantial lead in competition with both new and established products were in a better position to adopt skimming pricing. The study noted that skimming had a positive effect on profitability of insurance companies.

The third objective was to establish the effect of penetration pricing strategies on the profitability of insurance firms in Kenya.Penetration pricing was a strong determinant of insurance company's profitability. This was concluded because insurance companies had put in place effective penetration pricing practices which enabled them secure a wide market acceptance hence a bigger customer base and also the strategy helped them discourage competition in that it focused more on acceptance rather than profits.

The forth objective was to establish the effect of premium pricing strategies on the profitability of insurance firms in Kenya. It can be concluded thatfirms had successfully adopted effective premium pricing strategies in the recent years and strategies had yielded more sales in their insurance products. The price optimization strategies had a positive effect on profitability of insurance companies and were a key determinant of the insurance companies' performance.

The fifth objective was to establish the effect of price optimization strategies on the profitability of insurance firms in Kenya.It can be concluded that insurance companies had put in place effective price optimization strategies in that they used price increases and decreases to achieve price optimization of the everyday business. This had led to increase in sales and consequently increased returns in terms of profits. The study further noted that price optimization strategies had a positive effect on profitability of insurance companies

\subsection{Recommendations}

\subsubsection{Recommendations for study findings}

The study recommends that insurance companies put in place measures assess the most effective pricing strategy to reduce product costs and thus increase profitability whenever such a strategy is used. They should also adopt ways to implement their pricing strategies better compared to competitor firms. They should also ensure that the strategies they adopt help them discourage competition and focus more on both acceptance and profits.

\subsubsection{Recommendations for Further Research}

This study was not exhaustive by any means and therefore it is suggested that another study be conducted in the insurance industry in probably using the same variables so as to establish whether the findings of this study will hold true for individual products since the risk rating is different from one product to another with special focus on Medical and Motor private classes . 
International Journal of Finance And Accounting

ISSN xxxx-Xxxx (Paper) ISSN 2518-4113 (Online)

Vol.2, Issue 6, No.3 pp 44- 65, 2017

\section{REFERENCES}

Adam, D. (1970).Consumer Reactions to Price, in B. Taylor and G. Wills, eds., Pricing Strategy, (Brandon Systems Press, Princeton, New Jersey), 75-88.

Ahmed, N., Zulfqar, A. \&Ahmad, U. (2011). Determinants of Performance: A Case of life Insurance Sector of Pakistan International Research Journal of Finance and Economics ISSN 1450-2887 Issue 61 (2011).

Akerlof, G. (1970).The Market for Lemons. Quarterly Journal of Economics 84 : 488-500.

Andersen,T. J. (2008h).The Performance Relationship of effective Risk Management: Exploring the firm-specific investment Rationale. Long Range Planning 4(12) 155-176

Bain, J.S. (2001).Relation of Profit Rate to Industry concentration: American manufacturing, 1936 - 1940, Quarterly Journal of Economics, 65: 293-324.

Bain, J.S.(1996).Barriers to New Competition, Their Character and Consequences in Manufacturing Industries (Cambridge, MA: Harvard University Press).

Bajtelsmit, V. L.\&Bouzouita, R. (1998).Profit and Concentration in Commercial Automobile Insurance Lines .Journal of Insurance Issues 21(2) 175-182

Besanko, D. \&Wayne, L. W. (2000).Optimal Price Skimming by a Monopolist Facing Rational Consumers.Management Science 36 (5):555-567.

Bhattacharya U. \&Dittmar,A (2001).Costless Versus Costly Signaling: Theory and Evidence from Share Repurchase working paper, Kelley School of Business,University of Indiana, 2001.

Black, F.\& Scholes, M. (1973). The Pricing of Options and Corporate Liabilities.Journal of Political Economy 81,637-654.

Breedon, D.T. (1979). An lntertemporal Asset Pricing Model with Stochastic Investment and Consumption Opportunities.Journal of Financial Economics 6, 273-296. 
International Journal of Finance And Accounting

ISSN xxxx-Xxxx (Paper) ISSN 2518-4113 (Online)

Vol.2, Issue 6, No.3 pp 44- 65, 2017

Matt, C.1., Richtel, M.\& Andrew, R. S. (2004).At\&T Wireless for Sale as a Shakeout Starts. New York Times, Jan 21,

Chandran, E. (2004).Research Methods; A quantitative approach with Illustration. From Christian Ministries: Nairobi Daystar University

Cooper, D.R. \& Schindler, P.S. (2008).Business Research Methods, 10th Edition, New York, McGraw-Hill, 183.

Cox, J. D. and Rubinstein, M. (1985) .Options Markets. (Englewood Cliffs, N.J.: Prentice-Hall).

Cummins, J. D (1988a).Risk-Based Premiums for Insurance Guaranty Funds. Journal of Finance 43, 823-839.

Cummins, J. D. (1988b) Capital Structure and Fair Profits in Property-Liability Insurance, working paper, University of Pennsylvania

Ekundayo, O.A. (2012). The Impact of Risk Pricing on Profit Maximization of Insurance Companies, International Journal of Academic Research in Economics and Management Sciences Vol. 1, No. 4 ISSN: 2226-3624 21

Emory, F. (1970).Some Psychological Aspects of Price, in B. Taylor and G. Wilbro, eds., Pricing Strategy, (Brandon Systems Press, Princeton, New Jersey), 98-1 11.

Flanagan, R. and Norman, G. (2006).Pricing Policy, in Hillebrandt, P.M. and Cannon J. (eds), The Management of Construction Firms - Aspect of Theory, Macmillan, pp. 129-153

Fornell, C., Michael D. J., Eugene W. A., Jaesung, C. and Barbara E. B. (1999).The American Customer Satisfaction Index: Nature, Purpose, and Findings. Journal of Marketing 60 (4):7-18.

Gabor, A. and Granger,C. (1966).Price as an Indicator of Quality: Report on an Inquiry, Economica 33, 43-70. 
International Journal of Finance And Accounting

ISSN xxxx-Xxxx (Paper) ISSN 2518-4113 (Online)

Vol.2, Issue 6, No.3 pp 44- 65, 2017

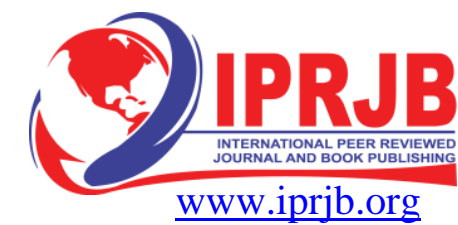

Harris, M. and Raviv, A. (1985).A Sequential Signaling Model of Convertible Debt Call Policy." the Journal of Finance 40(5): 1263-1281.

Heinkel, R. A(1982). Theory of Capital Structure Relevance under Imperfect Information the Journal of Finance 37 (5) 1141-1150.

Helson, H. (1964).Adaptation-Level Theory, (Haver and Row, New York, NY).

Hifza, M. (2011).Determinants of Insurance Companies Profitability: An Analysis of Insurance Sector of Pakistan, Academic Research International, Volume 1, Issue 3

Irwin, D. A.\& Peter, J. K. (2004). Learning-by- Doing Spillovers in the Semiconductor Industry.Journal of Political Economy 102:1200-1227.

Jarrow, R. (1988).Finance Theory (Englewood Cliffs, N J: Prentice-Hall).

Joskow, P. (2003). Cartels, Competition and Regulation in the Property-Liability Insurance Industry, Bell Journal of Economic and Management Science, 4(2), 375-427

Kahneinann, T. and Tversky,C. (1979).Prospect Theory: an Analysis of Decision Under Risk, Econometrica 47, 263-291.

Kallhoefer, R. and Salem, C. (2008).Profitability Analysis in the Egyptian Banking Sector.

Kasturi, R. (2006).Performance Management in Insurance Corporation .Journal of Business Administration online 5 (1)

Kennon, J. (2013). Return on Assets (ROA) Investing Lesson 4 - Analyzing an Income Statement. Retrieved from http: // beginnersinvest.about.com / od/ income statement analysis /a / return-on-assets-roa-income-statement.htm

Kerlinger, F. (1964).Foundations of behavioural research. New York: Holt. 
International Journal of Finance And Accounting

ISSN xxxx-Xxxx (Paper) ISSN 2518-4113 (Online)

Vol.2, Issue 6, No.3 pp 44- 65, 2017

Leland, H.E. and Pyle D.H. (1977) .Information Asymmetries, Financial Structure, andFinancial Intermediation.The Journal of Finance 32(2) : 371-387.

Markowitz, H. M. (1952).Portfolio Selection.The Journal of Finance.Vol 13(1)

Merton, R. C. (1973a).Theory of Rational Option Pricing.Bell Journal of Economics and Management Science 4, 141-183.

Merton, R. C. (1973b).An lntertemporal Capital Asset Pricing Model.Econometrica 41, 867-880.

Monroe, K. B. (1971).Measuring Price Thresholds by Psychophysics and Latitudes ofAcceptance, Journal of Marketing Research 8, November, 460-464

Mugenda, O. \&Mugenda, A. (1992).Research methods: Quantitative and qualitative approaches. Nairobi: Act press, 42-48.

Mugenda, O. M. and Mugenda, A. G. (2003).Research Methods: Quantitative and Qualitative Approaches, Acts Press, Nairobi-Kenya

Nehaus, G. R. and Harringhton, S. G. (2003).Risk Management and Insurance. Singapore, McGraw Hill/ Irwin Pub.

Nguyen, K. M. (2006).Financial Management and Profitability of Small and Medium Enterprises. Southern Cross University Thesis Submitted to the Graduate College of Management in partial fulfillment of requirements for the degree of Doctor of business. Administration. Paper Provided by the German University in Cairo Working Paper Series.

Niedrich, R W., Subhash, S. and Douglas, H. W. (2001) .Reference Price and Price Perceptions: a Comparison of Alternative Models, Journal of Consumer Research 28,

Parkin, M. (2003).Microeconomics, Addison Wesley, Boston.

Pass, C., Lowers, B. and Davies, L. (2000).Economics, Harper Collins Publishers, London. 
International Journal of Finance And Accounting

ISSN xxxx-Xxxx (Paper) ISSN 2518-4113 (Online)

Vol.2, Issue 6, No.3 pp 44- 65, 2017

Poitevin, M. (1989).Financial Signaling and the Deep-Pocket Argument.The Rand Journal of Economics 20(1) 26-40.

Putler, Daniel S., (1992).Incorporating Reference Price Effects into a Theory of Consumer Choice, Marketing Science 11, 3 , 287-309

Rebao, C. and Ann, W. (2004) .Determinants of Financial Health of Asian Insurance Companies, the Journal of Risk and Insurance Volume 71 Number 3.

Richtel, M. and Andrew R. S. (2004).At\&T Wireless for Sale as a Shakeout Starts.New York Times, Jan 21, 2004, C1.

Robinson, B. and Chet, L. (2005).Dynamic Price Models for New-Product Planning.Management Science 21 (10):1113-1122.

Ross, S.A. (1977) .Determination of Financial Structure: the Incentive-Signaling Approach. The Bell Journal of Economics 8 (1977): 23-40.

Sekaran, U. \&Bougie, R. (2010).Research Methods for Business :A Skill Building Approach. $5^{\text {th }}$ Edition.Aggarwal printing press, Delhi, ISBN: 978-81-265-3131-8

Sherif, M. and Horland, C (1961) .Social Judgment, (Yale University Press. New Haven,NY \)

Skitmore, R. A. (2007).Risk, Return, and Arbitrage, in I. Friend and J. Bicksler, eds., Risk and Return in Finance,v.I. (Cambridge, MA: Ballinger Publishing Co.)

Spence, M. (1973).Job Market Signaling.The Quarterly Journal of Economics 87(3) \355-374.

Stigler, G. L. (2004).A Theory of Oligopoly, Journal of Political Economy, 17(1): 69-8

Szymanski, D. M. and David H. H. (2001).Customer Satisfaction: A Meta-Analysis of the Empirical Evidence.Journal of the Academy of Marketing Science 29 (1):16-35. 
International Journal of Finance And Accounting

ISSN xxxx-Xxxx (Paper) ISSN 2518-4113 (Online)

Vol.2, Issue 6, No.3 pp 44- 65, 2017

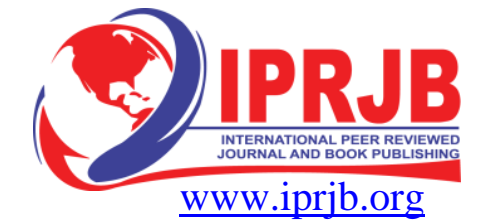

Talmor, E. (1981).Asymmetric Information, Signaling, and Optimal Corporate FinancialDecisions" Journal of Financial and Quantitative Analysis 16(4) 413-435

Varki, S. and Mark, C. (2001).The Role of Price Perceptions in an Integrated Model of Behavioral Intentions.Journal of Service Research 3 (3):232-240.

Voss, G. B., Parasuraman, A. \&Dhruv G. (1998).The Roles of Price, Performance, and Expectations in Determining Satisfaction in Service Exchanges. Journal of Marketing 62 (4):46-61.

Winer, Russell S. (1988).Behavioral Perspectives on Pricing: Buyers' Subjective Perceptions of Price Revisited, in Devinney, T. M., ed., Issues in Pricing: Theory and Research, (Lexington Books, Lexington, MA), Chapter 